\title{
ИСТОРИЧЕСКАЯ ПАМЯТЬ
}

И. В. Волкова

DOI: $10.7256 / 2222-1972.2013 .5 .9248$

При иитировании этой статьи сноска на доі обязательна

\section{Код Федотова: опыт прочтения дневника московского школьника}

\begin{abstract}
Аннотация: в статье анализируется один из самых ярких документов личного происхождения, раскрываюиий внутренний мир, творческие искания, систему жизненных правил и отношений с сочиумом одаренного советского юноши, жившего в Доме правительства на Берсеневской набережной. Личность Льва Федотова давно привлекала к себе внимание писателей, журналистов и кинематографистов нераскрытой загадкой главного предмета интересов и занятий. В статъе на базе лингвистических и логчческих методов анализа текста реконструируется большой исследовательский проект, в одиночку выполнявшийся московским школьником на протяжении ряда лет и представлявший собой оригинальную переработку кониепиии космиста Н.Ф. Федорова под углом зрения научных, сочиальных и идеологических приоритетов 1930-х г2. Планетарный масштаб замыслов и незаурядные аналитические, прогностические способности автора, подтвержденные его блестящей футурологической разработкой о Второй мировой войне, обусловливают исключительный статус дневника в ряду аналогичных хроник частной жизни.
\end{abstract}

Annotation: This article analyzes one of the most vivid documents of personal origin, revealing the inner world, creative search, system of rules for living, and relations in the society of a gifted Soviet youth who lived in a Government House on the Bersenevskay a waterfront. The personality of Lev Fedotov long attracted the attention of writers, journalists, and cinematographers for the undisclosed mystery of his main object of interest and activities. In this article, on the basis of linguistic and logical methods of analysis of the text, a large research project is reconstructed that was performed alone by a Moscow school boy over several years; it represents the original processing of the concepts of cosmist N. F. Fedorov from the perspective of scientific, social, and ideological priorities in the 1930s. The grand scale of concepts and remarkable analytical, prognostic capabilities of the school boy-confirmed by his brilliant futurological elaboration of the Second World War-create exclusive status for the diary in a series of analogous chronicles of a private life.

Ключевые слова: философия общего дела, биокосмические проекты, прогнозирование событий, биологическая эволюиия, психологическая регулячия, информахионная матриха личности, сохранение информаиионного следа, реконструкиия личности, морально-нравственное преображение человечества, обретение бессмертия.

Key words: philosophy of a common affair, biocosmic projects, prognostication of events, biological evolution, psychological regulation, informational matrix of personality, preservation of information trail, reconstruction of personality, moral transformation of humanity, attainment of immortality.

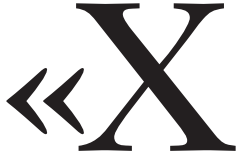

отя сейчас Германия находится $c$ нами в дружественных отношениях, но я твердо убежден (и это известно также всем), что это только видимость. Я думаю, ито этим самым она думает усыпить нашу бдительность, чтобы в подходящий момент всадить нам отравленный нож в спину. Эти мои догадки подтверждаются тем, что германские войска особенно усиленно оккупировали Болгарию и Румынию, послав туда свои дивизии. Когда же в мае немиы высадились в Финландии, то я твердо приобрел уверенность о скрытной подготовке немиами нападения на нашу страну». Так начиналась запись московского школьника Льва Федотова (1923-
1943) из Дома правительства на Берсеневской набережной о предстоящей (!) войне с Германией, сделанная в личном дневнике 5 июня 1941 г.

Вразрез с идеологемой о разгроме противника «на чужой территории», «малой кровью» за несколько недель, разделяемой подавляющим большинством жителей страны, автор дневника рисовал удручающую картину потерь и поражений, обусловленных, с его точки зрения, как внезапностью нападения фашистских захватчиков, так и недостаточной подготовленностью СССР к войне. При этом он являлся горячим патриотом советской страны, убежденным и в том, что за ней - конечная по- 


\section{Исторический журнал: научные исследования № 5 (17) • 2013}

\section{DOI: $10.7256 / 2222-1972.2013 .5 .9248$}

беда над фашизмом, и в том, что именно она прокладывает путь в будущее, основанное «на правде, честности, равенстве, свободе». ${ }^{1}$ Однако ознакомимся с его дальнейшими размышлениями о войне:

«Рассуждая о том, ито, рассовав свои войска вблизи нашей гранищы, Германия не станет долго ждать, я приобрел уверенность в том, ито лето этого года будет у нас в стране неспокойным... Я думаю, что война начнется или во второй половине этого месяиа (т. е. июня), или в начале июля, но не позже, ибо ясно, ито германиы будут стремиться окончить войну до морозов...

Я лично твердо убежден, что это будет последний наглый шаг германских деспотов, так как до зимы они нас не победят... To, ито немиы страшатся нашей зимъ,- это я знаю так же, как и то, ито победа будет за нами!..

Победа-то победой, но вот то, ито мы можем потерлть в первую половину войны много территории, это возможно...

Как это ни тяжело, но вполне возможно, ито мы оставим немиам, по всей вероятности, даже такие чентры, как Житомир, Виннича, Витебск, Псков, Гомель, и кое-какие другие. Что касается столии наших старых республик, то Минск мы, очевидно, сдадим; Киев немиы также могут захватить, но с непомерно большими трудностями.

О судъбах Ленинграда, Новгорода, Калинина, Смоленска, Брянска, Гомеля, Кривого Рога, Николаева и Одессы - городов, лежаших относительно невдалеке от границы, я боюсь рассуждатъ. Правда, немиы, безусловно, настолько сильны, что не исключена возможность потерь и этих городов, за исключением только Ленинграда.

То, ито Ленинграда немиам не видать, это я уверен твердо. Ленинградиъ - народ орль!! Если же враг и займет его, то это будет лишь тогда, когда падет последний ленинградеи. До тех пор, пока ленинградиы на ногах, город Ленина будет наш! То, что мы можем сдать Киев, в это я еще верю, ибо мы будем его защищать не как жизненный центр, а как столииу Украины, но Ленинград непомерно важнее и ченнее для нашего государства...

За Одессу как за крупный порт мы должны, помоему, бороться интенсивнее, чем даже за Киев, ибо Одесса иеннее последнего, и я думаю, одесские моряки достойно всыпят германцам за вторжение в область их города. Если же мы и сдадим по вынуждению Одессу, то с большой неохотой и гораздо позже Киева, так как Одессе сильно поможет море.

${ }^{1}$ РГАЛИ. Ф. Л. М. Рошаля. Дневник Л. Ф. Федотова. Тетрадь XV. С.8 (здесь далее: авторская нумерация страниц).
Понятно, ито немиы будут мечтать об окружении Москвы и Ленинграда, но, я думаю, они с этим не справятся; это им не Украина, где вполне возможна такая тактика. Здесь же дело касается жизни двух наших главнейших городов - Москвы как столичы и Ленинграда как жизненного промышленного и культурного иентра...

Окружить Ленинград, но не взять его фашисты еще смогут, ибо он все же сосед гранищы; окружить Москву они, если бы даже и были в силах, то просто не смогут это сделать в области времени, ибо они не успеют замкнуть кольио к зиме - слишком большое тут расстояние. Зимой же для них районы Москвы и дальше будут просто могилой!» 2

Мы привели в сокращении выдержку из дневника, которая на излете советской эпохи стала известна широкому кругу читателей, а имя автора прогремело на всю страну. И это, вопреки отсутствию формальных предпосылок для подобной славы! Ведь он прожил очень короткую жизнь, окончив перед войной только девять классов школы; погиб на фронте, не успев совершить подвигов; а его личный архив из научнофантастических романов, альбомов с рисунками и пятнадцати тетрадей дневника, за малой толикой, уничтожили война и послевоенный разор.

Вначале о незаурядном подростке, прозванном когда-то в школе «Гумбольдтом», «Леонардо из 7 Б», поведал его друг детства Юрий Трифонов: в романе «Дом на набережной» он вывел его в образе Антона Овчинникова. А в интервью «Литературной газете» от 5 октября 1977 г. писатель рассказал о реальном прототипе: «... В детстве меня поразил один мальчик.... Он был так не похож на всех! С мальчишеских лет он бурно и страстно развивал свою личность во все стороны, он поспешно поглощал все науки, все искусства, все книги, всю музыку, весь мир, точно боялся опоздать куда-то. В двенадцатилетнем возрасте он жил с ощущением, будто времени у него очень мало, а успеть надо невероятно много». Далее писатель перечислял все те разнообразные увлечения и занятия Левы, в которых он добился немалых успехов. Это и минералогия, палеонтология, океанография, рисование, музыка, физические тренировки по собственной системе, наконец, сочинительство романов - занятие, к которому он приохотил некоторых из своих друзей, в частности, Юрия Трифонова и Михаила Коршунова, ставших впоследствии известными писателями. По мнению

\footnotetext{
${ }^{2}$ Дневник Л. Федотова. Тетрадь XIV. C. 78-82.
} 
Трифонова, Лева Федотов был всесторонне развитой личностью, при этом сформировавшей себя совершенно самостоятельно. ${ }^{3}$

Однако и эти представления о давно ушедшем из жизни юноше оказались неполными. Некоторое время спустя, готовясь к премьере спектакля Ю.А. Любимова по своему роману в театре на Таганке, Ю. Трифонов попросил у матери Левы несколько сохранившихся тетрадей его дневника. Рассчитывая всего лишь отыскать кое-какие яркие детали из жизни обитателей дома, писатель нежданно-негаданно натолкнулся на поразительное по своей точности прогностическое описание Великой Отечественной войны, сделанное как минимум за две с половиной недели до ее реального начала. Эта находка поразила его и даже изменила сценарий спектакля: дневник Левы и некоторые из его героев, в частности, мать и тетка автора, стали его полноправными действующими лицами. А дальше... имя Левы Федотова, известное в узких кругах жителей Дома на набережной, разнеслось по стране. Этот мальчик снова возник в творчестве Трифонова - на этот раз как Леня Крастынь (Карась) - персонаж последнего, не оконченного романа писателя «Исчезновение». Ему посвятили пространные очерки известные журналисты О.Кучкина, А. Аджубей; полные восхищения и пиетета - мемуарные зарисовки бывшие школьные товарищи. ${ }^{4}$ В 1986 г. был снят талантливый документальный фильм А. Иванкина и Л. Рошаля - «Соло трубы» о чете революционеров Федотовых и их разносторонне одаренном сыне, вызвавший огромный всплеск интереса к его дневнику и личности. Но и в этой ленте сюжетный узел составило предсказание хода войны. А в 1989 г. Ю. Росциус - автор, специализирующийся на исследовании аномальных явлений, выпустил брошюру под характерным названием «Дневник пророка», где были воспроизведены те самые знаменитые страницы дневника. Эта публикация заложила трактовку личности автора как проводника неких трансцендентных сил, писавшего свои провидческие заметки о будущем в режиме автоматического письма. Причисленный к ведомству Нострадамуса Лева стал фигурантом многочисленных интернет - ресурсов футурологической направленности и занял

\footnotetext{
${ }^{3}$ Цит. по: Трифонова О. Р. О времени и о судьбе. // Трифонов Ю. Отблеск костра. Старик. Исчезновение. М.: Московский рабочий, 1988. С. 550.

${ }^{4}$ Наиболее интересны: Коршунов М. Терехова В. Тайны и легенды Дома на набережной. М.: Слово, 2002. 399 с.
}

почетное место в номинации «великие прорицатели будущего», его имя обросло домыслами и легендами, несмотря на то, что общий массив достоверных сведений о нем остался в границах первых газетных публикаций 1980-х гг.

А сам дневник, наделавший столько шума, в начале эпохи всеобщей приватизации как-то незаметно затерялся. Десятилетие спустя участники некоторых интернет - сообществ стали высказывать пессимистические предположения о его судьбе: о безнадежном повреждении текста недобросовестными держателями и даже о продаже его за границу, а соответственно об утраченной возможности прикоснуться к истории «человека - загадки». В самом факте периодически вспыхивающего к этому документу интереса кроется смутное ожидание возможных новых открытий.

И все же дневник есть... Он находится в РГАЛИ в составе фонда Л.М. Рошаля, хотя и не включенный в путеводитель, каталог и описи архива. Это четыре общие школьные тетрадки под номерами V, XIII, XIV, XV - уцелевшие в вихре войны, послевоенных пертурбаций в Доме на набережной и сохраненные матерью автора Р.Л. Маркус - Федотовой. Часть страниц надорвана и истрепана, выцветшие чернила порой трудно читаются, но все-таки подлинник доступен для изучения. Именно в его полном тексте кроется ключ к феномену Л. Федотова, а можно сказать, в его лице и к социокультурному коду поколения, сгинувшего на полях сражений Великой Отечественной. Принеся священную жертву на алтарь Отечества, оно одновременно лишило его альтернативы послевоенного развития, заложенной в потенциях и стремлениях своего образованного, даровитого и деятельного костяка.

Кардинальный вопрос, который возникает по ходу чтения дневника, состоит в мотивах автора и в предназначении, которое он отводил своей хронике. Как следует из его собственного упоминания, идею подал его лучший взрослый друг Саша. О последнем известно очень мало: он был хорошим знакомым семьи еще с дореволюционных времен, когда родители Левы - Федор Каллистратович Федотов и Роза Лазаревна Маркус жили в США, и, по-видимому, вместе с другими эмигрантами левых политических взглядов вернулся на родину после 1917 г. С ним и его женой Анютой Лева провел лето 1935 г. на Клязьме, где и начал вести дневниковые записи. Вскоре Саша умер, но в память о нем маль- 


\section{Исторический журнал: научные исследования № 5 (17) • 2013}

\section{DOI: $10.7256 / 2222-1972.2013 .5 .9248$}

чик продолжил составлять свои отчеты. Можно предположить, что до ноября 1939 г. этому занятию Лева предавался больше «по обязанности», нежели из личной заинтересованности: ведь за четыре с лишним года было исписано всего четыре тетрадки, да и то довольно размашистым почерком (который, кстати, сохранялся еще в $\mathrm{V}$-й тетрадке, - три последние будут заполняться убористо, почти бисерным почерком). Еще в августе 1939 г., как следует из его же признаний, критерием для отбора материала служила его большая или меньшая содержательность, оцениваемая как бы со стороны. На этом основании, в частности, он не стал описывать в дневнике времяпрепровождение с любимыми ленинградскими родственниками, которые гостили у них в Москве в августе, так как, по собственному признанию, не усмотрел в этом сюжете ничего занимательного. Но уже в дневниковой записи от 23 ноября 1939 г. он горько раскаивался в пренебрежении этим эпизодом своей жизни.

«... Я теперь жалею, что не записал их пребъвание в Москве! Тогда мне казалось, ито эти записи у меня будут лишние и скучные, а между тем, это было все очень интересным, и я это сейчас-то уже понимаю. Но, ничего, впредъ я буду умней!» 5

Итак, с ноября 1939 г. метод ведения дневника изменился. Темп повествования резко замедлился. Так, теперь отображение всего трех недель - с 17 ноября по 8 декабря потребовало целой тетради, а неполный год - с 9 декабря 1939 г. до 23 августа 1940 г.- занял 7 тетрадей, которые, увы, не дошли до нас. Как это следует из авторских пояснений, материал стал иначе фильтроваться и подаваться. Именно к этому обновленному стилю относятся и некоторые безусловные парадоксы дневника. Первый из них: отсутствие сведений об источниках информации, которые питали естественнонаучные интересы автора. Как человек знания, нацеленный на научную работу в будущем, Лева, по свидетельству друзей, много читал. По их же воспоминаниям, он часто и подолгу проводил время в Зоологическом музее на Моховой. Однако тщетно было бы искать следы этих занятий в дневниковых текстах. Единственное упоминание книги, из которой он регулярно черпал полезную информацию, - «История земли» - относится к эпизоду отправки толстого письма родственникам в Ленинград: чтобы распухший конверт втиснулся в прорезь почтового ящика, его при-

\footnotetext{
${ }^{5}$ Дневник Л. Федотова. Тетрадь V. С. 17.
}

шлось подложить под пресс из этого самого фолианта. Приведенное наблюдение наталкивает на единственно возможный вывод: получение знаний, иными словами, поглощение результатов чужого труда, не задействовавшее креативного потенциала самого автора, сознательно исключалось из дневниковых хроник.

Примерно на том же принципе строится и описание повседневной жизни: если предмет создавал повод для эмоционального, интеллектуального или даже физического напряжения, то он подлежал запечатлению на бумаге. На этом основании из рассказов-отчетов о школьной жизни выпадает будничная рутина, а фиксируются только особые случаи, когда привычный распорядок ломается. Например, конфликт с учителем литературы Я. Д. Райхиным, вызванный отказом Левы участвовать в чтении по ролям драмы Островского «Гроза» по причине мучительной зажатости перед любым публичным выступлением. Или - проявления особого педагогического мастерства, например, учителем физики В.Т. Усачева, которому удавалось без обычных учительских санкций усмирить разбуянившихся подростков и одновременно доступно и остроумно объяснить трудные понятия по своей дисциплине. Либо те отдельные работы, которые требовали творческих усилий и выполнялись им не только по необходимости, но и с осознаваемой пользой для развития своих наклонностей, как например, подготовка экономико-географической карты Великобритании, рисунки к географическим альбомам, посвященным Италии и Украине. Область частной жизни представлена короткими сообщениями о частых приездах иногородних родственников, создававших тесноту в их маленькой квартирке, о походах в гости и приемах гостей. Или же - о спорах с матерью, теткой из-за нежелания учиться профессиональным приемам рисования, отказа менять свой скудный гардероб на время ленинградских каникул и надевать пальто до наступления сильных морозов, из-за своего намерения отправиться летом 1941 г. пешком в Ленинград.

События «большого мира» в дневнике отражены в небольшом объеме и очень избирательно. Тема советско-финской войны 1939-1940 гг. возникает и приковывает внимание, главным образом, в связи с запланированной на зимние каникулы 1940 г. и сорванной в конечном итоге поездкой в Ленинград. При этом восприятие военной кампании целиком и полностью определяется освещением советской печати и про- 
паганды и не выдает ни малейшего стремления автора более или менее самостоятельно осмыслить ее уроки. Далее вопросы международной политики практически исчезают из записей примерно годичной продолжительности (с августа 1940 г. по июнь 1941 г.). И вот парадокс номер два: в самом конце XIV тетради, под датой 5 июня вне всякой связи с предыдущим содержательным заполнением размещается глубокий аналитический разбор будущей схватки СССР с гитлеровской Германией. Именно эта вставная новелла, которая принесла известность дневнику и его автору, в наибольшей степени интригует неявными мотивами и обстоятельствами своего появления.

Знакомство с дневником позволяет выделить его несколько сквозных тем: музыкальные увлечения, в особенности, впечатления и размышления о творчестве Дж. Верди и в первую очередь об опере «Аида»; художественно - изобразительные опыты, включая и изучение и зарисовки Исаакиевского собора, который он считал таким же шедевром в архитектуре, как «Аиду» в музыке. Это - поездка в Ленинград и долгая подготовка к ней; наблюдения за природой и спуск в подземелье; школьные дела, освещаемые преимущественно как неизбывная помеха любимым внешкольным занятиям. Наконец, это общение с родственниками, знакомыми семьи, друзьями, любимыми учителями, а также игры и разговоры с маленькими детьми.

Львиная доля материала подается через призму диалогов, в которых автор педантично фиксировал не только разговорную нить, но даже междометия и, насколько позволяет письменная передача, интонации говорящих. Скрупулезное и точное воспроизведение всей беседы требовало от него больших усилий. И здесь всплывает третий парадокс: подросток, дороживший каждой свободной минутой и жертвовавший ради внешкольных увлечений прогулками, а часто и приемами пищи, расточительно тратил свое время на запись мелких деталей разговора, будь то с другом, родственником, учителем или даже едва знакомым ребенком. Эта своего рода мания «воспроизведения» вызывала тем большее недоумение у окружающих, что никакого мало-мальски исторического значения, с общепринятой точки зрения, записываемые разговоры не имели. Иными словами, овчинка не стоила выделки. Такое ощущение, например, у Юрия Трифонова, оставила их последняя «проходная» встреча в булочной на Полянке, в конце которой Лева пообещал: «Я и эту встречу в булочной запишу. И весь наш разговор. Потому что все важно для истории». ${ }^{6}$ Иногда приверженность этому правилу вызывала насмешки. А иногда ставила его в неловкое положение: некоторых собеседников Левы, например, учителя музыки Модеста Николаевича Робера и его жену Марию Ивановну, похоже, не всегда радовала перспектива быть запечатленными в каждой своей реплике на страницах дневника. Тень их неудовольствия проскальзывает в разговоре о выборе жизненного пути и смысле будущей деятельности Левы.

«- Я уверен, что ть не пропадешь! - сказал М.Н. - Раз у тебя столько склонностей, то из тебя выйдет весъма полезный человек.

Я молчал. ла М.И.

- ...который должен получить орден, - добави-

- Ну, орден это другое совсем дело, -возразил М.Н.

- Нет. Нет! Без ордена я не признаю.

- Главное, чтобы принести полъзу стране, - сказал я, - а орден или похвала - это дело десятое. Если тъ человек образованныи, грамотный, ученый, умеюший приносить обществу пользу, то этого уже достаточно. Тъ и без ордена будешь таким же. Орден только подтверждает пользу человека, а иенят человека (за-пропуш. И.В.)его знания и способности.

- Это правильно, - согласился М.Н. - Скромность прежде всего.

- Боже! - проговорился я. - Как я только все это запишу в дневник? Ведъ я забуду все эти разговоры! Уж лучше я сразу ушел бы домой после занятий!

- Вот он зачем тут сидит!!! - вскричал М.H.». ${ }^{7}$

Как бы то ни было, Лева продолжал свою работу в прежнем ключе. На первый взгляд, в подобном способе ведения дневника усматривается подспудное стремление компенсировать дефицит доверительного общения в реальной жизни, что в целом характерно для замкнутых подростков. Подобное допущение было бы правомерно, например, в отношении сверстника Левы, сына М. Цветаевой - Георгия Әфрона, которому личный дневник тех же лет частично восполнял отсутствие товарищеской среды. Однако эта схема не подходит для Левы. При всей своей неформатной интеллектуально-психологической организации он совершенно не был отщепенцем. У него были близкие друзья (Миша

\footnotetext{
${ }^{6}$ Трифонов Ю. Дом на набережной. Повести и рассказы. М.: Детская литература, 2001. С. 242.

${ }^{7}$ Дневник Л. Федотова. Тетрадь V. С. 13
} 


\section{Исторический журнал: научные исследования № 5 (17) • 2013}

\section{DOI: $10.7256 / 2222-1972.2013 .5 .9248$}

Коршунов, Женя Гуров, Олег Сальковский, Дима Сенкевич, Юра Трифонов), теплые и открытые отношения связывали его с учителем музыки Модестом Николаевичем и его женой Марьей Ивановной, интеллигентной родней из Ленинграда - виолончелистом Фишманом Эммануилом Григорьевичем и его женой - художницей Раисой Самойловной.

а и само построение дневника ясно указывает на то, что он не предусматривался только для индивидуального пользования. В тексте то и дело встречаются прямые обращения к читателю, которого автор видел явно за пределами своего окружения. Именно для удобства этого неведомого читателя Лева, вводя в действие или упоминая заново после долгого перерыва того или иного героя своего повествования, Лева сообщал о нем необходимые справочные данные и хотя бы в нескольких фразах набрасывал его визуальный портрет. С фрагментами дневника он охотно знакомил М.Н. Робера, родственников в Ленинграде и некоторых других лиц - вероятнее всего для того, чтобы получить обратную связь со сторонним читателем. Коль скоро ни личные планы Левы, ни тем более издательская политика его времени не допускали возможности публикации дневника в текущем или обозримом будущем времени, то, напрашивается единственный вывод: как бутылку с запечатанным посланием Лева направлял свой труд по волнам времени.

Такой вывод, однако, не уменьшает количества вопросов. Похоже, что и людям, знакомым с частями этого произведения, были непонятны намерения автора, а сам Лева не торопился их открывать. В этом отношении характерен диалог с Модестом Николаевичем, который состоялся после прочтения Левой ему записи за 6 ноября 1939 г.:

«-Твой дневник прямо хоть иелой книжкой издавай, - сказал потом М.H.

- Ну-у, до этого еше далеко, - сказал я.

Ну, а вообще-то, зачем нужно вести дневник? проговорил М. H.

- Ведъ каждую работу следует производить не только для пользы самому себе, но и для того, итобы принести пользу другим, а так же и стране.

- Это вполне понятно, - согласился я». ${ }^{8}$

Правда, на этом интересном месте разговор переключился на другую тему, а загадка осталась. Еще больше взвинчивает интригу неболь- шой манифест фундаментальных принципов освоения мира, на которых, по его убеждению, держится подлинная наука, и непререкаемых для него самого: «... знать только для того, итобъ держать груз в голове, как пустой балласт и не иметь возможностей применять его - это рабское, тупое преклонение перед наукой. Зачем же тогда человечество имеет лозунг: "Без практики наука не существует!»?... Я сторонник разносторонних знаний только в том случае, когда из всех них можно извлечь пользу, применить в жизни и когда они, по крайней мере, дополнялот друг друга и взаимно помогают! Видимые же разносторонние знания без применения и пользы от них, это не знания, а дырка от баранки, пустота, ненужный поглотитель рабочего времени» ${ }^{9}$.

Итак, утилитаризм познания, дополненный интеграцией разных направлений поиска. Много нужного, но ничего лишнего! В этой системе координат развивались и увлечения Левы, а их разнообразные линии сходилось в определенном контрапункте. Для его выявления следует обратить внимание на повторяющиеся мотивы дневника, а за его пределами - и известной части архива Левы. В значительной части образцов его литературной и научно-изыскательской деятельности, включая и сам дневник, присутствует один общий пространственно - «геодезический» сюжет. Это - погружение под землю.

В подземелье наступает развязка сюжета столь любимой им оперы Верди: здесь во владениях египетской богини Исиды обретают вечный покой и соединяются души приговоренного к смерти Радомеса и его возлюбленной Аиды. Интересно, что финал сюжета оперы Лева прописывает полностью в своем дневнике.

Характерно, что и в Левином литературном творчестве маршруты героев ведут под землю. Из дневника можно узнать, что он писал роман «Кобольд, или путешествие в недра земли» (сохранился лишь небольшой фрагмент о геологах, пробирающихся через расставленные им ловушки басмачей к месту предстоящих разысканий). Напомним, что именем, фигурирующим в названии романа, в германской средневековой мифологии было принято называть инфернального обитателя подземного мира, яростно охранявшего его сокровища от посягательств людей. Опять-таки из дневника известно, что Лева писал роман «Подземный клад». Именно он и побудил его друзей - М. Коршунова и О. Сальковского пригласить его в 
путешествие по подземелью, которое начиналось из подвала церкви Николы на Берсеневке. 8 декабря 1939 г. - день этой подземной экспедиции, безусловно, стал важнейшим в Левиной биографии. Ему отводилось большое место в V и VI тетрадях, хотя из-за утери VI тетради описание остается оборванным.

Не в пример своим товарищам, для которых это было просто ребячьей забавой, Лева сразу ставит дело на научную основу, тщательно продумывая техническое снаряжение, включая свечи, спички, веревку, а также тетрадь и карандаш с циркулем. Последние принадлежности требуются для документирования экспедиции: зарисовок увиденного и записей своих впечатлений, в том числе фиксации тех слов, которые будут ими произнесены за время, проведенное под землей. Друзьям он кратко и уклончиво объясняет: «Это все нам впоследствии может пригодиться с научной точки зрения». В ожидании экспедичии он с нетерпением представлял себе «мрачные темные ходы, сырые и жуткие, зловещие залы с плесенъю по стенам, подземные переходы, колодиъ». Однако прохождение через подземнъе тоннели на деле оказывается еше более волнуюшим, чем это представлялось накануне: "Сердие у меня бешено колотилось, в груди давило, и от этой ужасной тесноты выработалось какое-то необвяснимое, странное, неприятное чувство... Эти жуткие подземелья как бы давили на все мое сознание, и я чувствовал себя сдавленным и стиснутьмм не только физически, из-за узкого коридора, но и морально... Не прошли мъь и нескольких шагов от двериы, как коридор под прямым углом повернул вправо и сделался еще уже прежнего. Я нахмурился $u$ сжал кулаки». ${ }^{10}$

Записи дают ясно понять, что подземелье вызывало у него прямую ассоциацию со склепом. Отсюда проистекали и такие специфические физиологические реакции, как удушье, ощущение физической и моральной сдавленности и еще некоторые незнакомые чувства. Сужение последнего пройденного коридора нагнетает эти эмоции, одновременно ставя преграду дальнейшему продвижению вглубь лабиринта. Иными словами, подойдя к кульминационной точке, путешествие в царство теней и намеченная программа обследования застопориваются. Это вызывает у Левы сильнейшее волнение. Его маркирует заключительная фраза приведенного отрывка. Выражения «сжать кулаки», «стиснуть зубы», «сжать губы», используемые несколько

\footnotetext{
10 Дневник Л. Федотова. Тетрадь V. C. 64, 66, 92.
}

раз в дневниковых рассказах Левы от первого лица, помечают ситуации его сверхвысокого нервного возбуждения, а обозначенная ими моторика сродни бойцовской стойке перед лицом атакующей враждебной силы.

Дважды они встречаются в рассказе о спуске в подземелье: в первый раз, когда, пройдя подвалы со следами человеческой жизнедеятельности в виде старого хлама, они открывают проржавевшую дверцу в глубины подземелья - на территорию абсолютного безмолвия и неизвестности, а во второй раз - когда убеждаются, что дальше хода нет. Складывается впечатление, будто в эти моменты он вступает в напряженный поединок с невидимым противником. Для некоторого прояснения импульсов Левы сравним описанные ситуации с другим примером идентичной реакции: как-то, возвращаясь от Анюты, они вдвоем с матерью вспоминают ее мужа, покойного друга семьи Сашу: «-Какой хороший и умный был человек, - проговорила мама. Всякие балбесы да пьянищы живут, и ничего, а полезнъе люди умирают... Я ничего не ответил и только сжал плотнее губъ...» 11

Общим во всех эпизодах является не только психофизическое движение отпора, но и объект, на который оно направлено. Это - смерть, которая, слепо выбирает жертвы, унося их в невозвратную тьму.

Не вызывает сомнений: путешествие в подземные чертоги, пусть и носило разведывательный и тренировочный характер, было связано с неким планом обуздания хищной власти той, которая несколько раз встречалась и на его коротком веку. Впервые это произошло в 1933 г., когда на Алтае при невыясненных обстоятельствах погиб его горячо любимый отец. Несколько лет спустя он потерял близкого друга Сашу. Обжигающее воздействие этих «встреч» проявляется как в убыстряющемся темпе его собственной жизни, подмеченном Ю. Трифоновым, так и в трезвом осознании биологически отмеренных рамок всякого человеческого существования.

Вряд ли случайным является тот факт, что в дневнике Левы в абсолютном большинстве случаев слова «мужчина», «женщина», «человек», «люди» заменяются одинаковым определением - «смертный» и «смертные». Но травматический смысл проблемы для него не измерялся только личными потерями. С 1937 г. в нем прорастает тревожное ощущение надвига-

\footnotetext{
11 Дневник Л. Федотова. Тетрадь V. C. 18.
} 


\section{Исторический журнал: научные исследования № 5 (17) • 2013}

\section{DOI: $10.7256 / 2222-1972.2013 .5 .9248$}

ющееся глобальной катастрофы. По-видимому, в то время он еще не вполне был готов к ее вербальному выражению, поэтому создал графический образ. На рисунке, озаглавленном «Троянский конь» двое чернорубашечников со свастикой на рукаве целятся в безоружного человека, приставленного к стенке. Изображение почти кричит: это только начало работы убийственной машины. Из чрева нацистского коня, установленного в сердцевине Европы, разлетятся по свету еще сотни и тысячи таких же адских машин. В 1939 г. сгущается его предчувствие приближающейся беды для СССР, хотя, казалось бы, пакт Молотова- Риббентропа ее отодвинул. А в 1940 г. предчувствие перерастает в уверенность. 13 декабря 1940 г., проводив на вокзал своего дядю Марка, уезжавшего домой в Николаев, Лева записал в дневнике: «Мне было не очень-то легко прошаться с ним... Я также поехал на вокзал, в одном из модных вокзальных залов мы простились, и я вернулся домой... Я задавал себе вопрос, увижу ли я когда-нибудь своего дядю или нет?.. Мне теперь все в нем было дорого...» 12

В контурах грядущей войны, которые у него начинают складываться в 1939 г., он усматривает и высокую вероятность применения таких средств массового уничтожения, как химическое и бактериологическое оружие. Резонно предположить, что в этом случае спасением для большой массы людей могли бы стать обширные подземные убежища, рассчитанные на долговременное пребывание. Однако Левины записи свидетельствуют о том, что его интерес к подземным угодьям был мотивирован не только этим обстоятельством. Ключ к некоему далеко идущему замыслу, который направлял его мысли и действия, могут дать, с одной стороны, полупрозрачные и односложные ответы, которые он дает на расспросы родственников о выборе профессии, с другой, - следы его творческих занятий предвоенных полутора лет. В 1940 г. на вопрос дяди о том, какие же отрасли знания его привлекают больше других, он отвечает:

«- Больше всего меня влекут к себе биология и геология - природоведческие науки; природа, короче говоря.

- Да, природа - это самое интересное! - согласился мой дядя. - Тут я с тобой согласен... Зоология, ботаника - это самое занимательное из того, что я знаю. В природе нет каких-нибудь зльх хитростей, там все просто - умей только правильно разгляды-

\footnotetext{
${ }^{12}$ Дневник Л. Федотова. Тетрадь ХІІІ. С. 34.
}

вать и открывать ее законы! Эти слова Исаака мне очень понравились» 13 .

Отголоски данной беседы с полюбившейся Леве формулой изучения природы слышны и в разговоре с двоюродной сестрой Раей о выборе будущей сферы профессиональной деятельности, которую он определяет так: «... геология 8 лице минералогии и палеонтологии и биология в лице зоологии. Теперь остается ждать,... какая из них победит другую. А для жизни человека обе они чрезвычайно важны: геология питает промыиленность и многие другие отрасли хозяйства свочм изучением и использованием минеральных богатств, а зоология помогает человеку развивать свое хозяйство, улучшать продукты питания и даже разгадывает новые загадки в природе, ответ которьх помогает жить, давая новую энергию нам». ${ }^{14}$

Дневник доносит сухой и немногословный отклик собеседницы на это заявление: она коротко одобрила его выбор. Однако, вероятнее всего, ответ ее не сильно заинтересовал. Да это и неудивительно: только чуткий слух, настроенный на Левину «волну», за этим полупризнанием мог уловить нечто большее, чем банальное рассуждение о народнохозяйственной пользе геологии и биологии и метание между этими науками разбросанного юнца. И, тем не менее, пусть витиевато и нескладно, в конце монолога Лева проговаривается любимой двоюродной сестре о мега-цели своих исканий. Это - выход на новые әнергетические источники жизнеобеспечения человека. Как можно судить по косвенным показаниям Левы, к этой цели должны привести его палеонтологические изыскания. На такое заключение наводит очевидная неравноценность объектов исследовательского интереса, обозначенных им в геологии и зоологии. В первой палеонтология и минеральные запасы, питающие промышленность, во второй, помимо подспорья народному хозяйству и продовольствию, некая завораживающая загадка природы, которая, по его намекам, обещает прорыв в жизнедеятельности всей человеческой популяции. Сама подача этих объектов дает ясно понять, что именно последний из них обладал абсолютной притягательностью для пытливого подростка. В то же время раскрытие загадки было опосредовано опорой как на зоологию, так и на геологию - в противном случае отсылка к геологии была бы явно излишней, а пальма первенства

\footnotetext{
${ }^{13}$ Дневник Л. Федотова. Тетрадь XIII. С. 33.

${ }^{14}$ Дневник Л. Федотова. Тетрадь XIV. C.6.
} 
безраздельно была бы отдана зоологии! В свою очередь этот тандем снова уводит в геологические выработки и природные полости гор, которые являются местом находок доисторических животных и растений.

На палеонтологию как на страсть друга детства указывал Трифонов в романе «Исчезновение»: литературный двойник Левы совершал бесстрашные одиночные вылазки в подмосковные пещеры, иногда увлекал туда друзей и даже создал конспиративную организацию «Общество по изучению пещер и подземных ходов» (ОИППХ). Правда, назначение этих обследований в романе оставалось малопонятным для привлеченных членов тайного общества. Между тем, у реального Левы был конкретный замысел, хотя он и не разглашал его даже самому близкому кругу. Что же касается неоконченного спора двух наук, о котором он сообщал родственнице, то, по всей видимости, его следует отнести к выбору направления профессиональной подготовки. Дело в том, что при всей своей соотнесенности и с биологией, и с геологией палеонтология в советских вузах, и в МГУ, в частности, была представлена на геологических или геолого-почвенных факультетах. Скорее всего, в отмеченный момент времени Лева решал для себя вопрос о том, в какую сторону ему двинуться с его установками в изучении палеонтологии - то ли углубления в область неживой природы, связанной с обучением геолога, то ли живой, предполагающей получение биологического образования. Сам факт этих колебаний указывает на особенность его мышления: похоже, грань между живой и неживой материей, по меньшей мере, в пространственных границах подземной среды для него была подвижной. Это представление нашло свое отражение в нескольких произведениях, увы, дошедших до нас только в описаниях - либо его собственных, либо посторонних.

О научно-фантастическом романе, которым Лева усиленно занимался в последний плодотворный период жизни февраля- апреля 1941 г., оставил краткое свидетельство Михаил Коршунов. По его словам, в нем речь шла о скрытом под землей невредимом очаге доисторической жизни, с фауной и флорой, давно исчезнувшими на поверхности земли. Это и был «подземный клад» в гигантской пещере с зелеными окаменелостями, бывшими некогда зеленым океаном. Он был найден группой современных естествоиспытателей по своеобразным меткам, оставленным древними людьми. Текст этого произведения Лева тщательно отделывал: по воспоминаниям М. Коршунова, он собирался его отдать для прочтения, а, возможно, и для публикации известному писателю и журналисту Александру Исбаху, с которым хорошо был знаком еще его отец. ${ }^{15}$ Однако война, уход на фронт Исбаха и отъезд Левы в эвакуацию помешали этому плану.

А вот художественная иллюстрация Левы, сделанная весной 1941 г., к тому же или другому своему роману «Кобольд, или путешествие в недра земли». Название рисунка - «Кобольд, или в пещере горного короля»- дает право на отнесение его и к тому, и к другому литературному опыту Левы. Несмотря на то, что рисунок, как и романы, не сохранился, подробное описание его привел сам автор в дневнике. На нем он изобразил гигантскую пещеру, заполненную безмолвными духами подземного короля, растущими из земли и из стен в форме косматых голов каменных старцев. В отличие от тяжеловесных неподвижных подданных король духов, не имевший тела, а только голову, состоял из газообразного вещества, наподобие молочной дымки. Размеры и пещерного королевства, и его обитателей, как подчеркивал сам Лева, превосходили любые наземные мегалитические сооружения. Если бы главному властелину этих мест «предложили нъю-йоркские небоскребъ, он их глотал иельми сотнями и только тогда бы заметил, что он действительно поглочает «какую-то мелочъ». ${ }^{16}$ Ан- $^{-}$ тропоморфные черты ископаемых, хотя бы и на иллюстрации к научно-фантастическому роману, указывают на определенный параллелизм наземных и подземных природных обителей, в частности на возможность разумной и одухотворенной населенности вторых в материальных формах, которые для первых считаются безжизненными. Конечно, это только полуоформленная гипотеза, к тому же поданная в художественно-фантастическом жанре, который вообще «заточен» на продуцирование невероятных идей. И, тем не менее, судя по страстной приверженности теме подземной жизни в литературных и художественных опытах, гипотеза его глубоко захватила. Можно выдвинуть предположение: подземные глубины он рассматривал как среду обитания человечества будущего.

Механизмы эволюции и формы адаптации биологических особей к изменениям в природе

\footnotetext{
${ }^{15}$ Коршунов М. Терехова В. Указ. соч. С. 36,179.

${ }^{16}$ Дневник Л. Федотова. Тетрадь XIV. С. 75.
} 


\section{Исторический журнал: научные исследования № 5 (17) • 2013}

\section{DOI: $10.7256 / 2222-1972.2013 .5 .9248$}

были сквозной темой естественнонаучных занятий Левы. Этому же сюжету была посвящена его единственная опубликованная заметка в детском журнале «Пионер» за 1938 год. А в конце 1940 г., вопреки обыкновению, в дневнике он рассказывал о прослушанной в музее Дарвина лекции об эволюции основателя музея профессора А.Ф. Котса, подытоживая впечатления в одобрительной оценке «старичка» как чрезвычайно полезного и «энергичного смертного». Интересно, что тогда же - в конце 1940 г. и в начале 1941 г. Лева трудился над последней из своих монументальных работ - художественной летописи Земли. Единственный видевший ее в готовом виде - Михаил Коршунов - свидетельствует: «Это было лучшее из Левкиных творений». ${ }^{17}$ Рулон белых обоев, который за счет подклеек мог легко удлиняться, как нельзя лучше подходил для выражения непрерывного и неоконченного процесса изменения форм и условий жизни. На нем были изображены плавающие, ползающие, бегающие, летающие биологические особи... Продолжение почти угадывается: после освоения высокоорганизованной жизнью воды, земли и атмосферы на очередь дня поставлены недра земли.

Размышления Левы над ходом эволюции определенно отсылают к дальним предвидениям К. Циолковского о космическом расселении человечества, которому будет сопутствовать и изменения самой физической оболочки уроженцев земли. Разница «ярусов» этой предстоящей экспансии для такого сравнения не принципиальна: ведь что такое недра земли, как не «космос наоборот», по выражению современного исследователя и публициста Яна Разливинского! 18

За робкими догадками московского школьника просматривается влияние и некоторых других идей русских «космистов». Это и принцип панпсихизма К.Э. Циолоковского, настаивающий на условности границ между органической и неорганической материей и на чувствительности, присущей частицам последней. Это и учение В.И. Вернадского, указывающее на наличие непрерывного тока атомов между живым и косным веществом биосферы, а также на развитие центральной нервной системы и увеличение объема мозга как магистральную линию в

\footnotetext{
17 Коршунов М. Рулон белых обоев.// Личный архив автора. C. 11.

18 Разливинский Я. Если бы. Путешествия к центру земли./ Мир фантастики. 2006. № 5 (33) // http://www.mirf.ru/archive. phpshow $=33$
}

эволюции человека. Этим представлением явно навеяны образы голов - пещерных насельников на иллюстрации Левы.

Однако, в любом случае, идеи грядущей колонизации новых миров и преображения телесного естества человечества оставались за гранью видимости и возможностей влияния науки середины XX столетия. А, между тем, короткая сознательная жизнь Левы устремлена к практическому делу, которое, по его мнению, не терпит отлагательства. В сущности, все его занятия, увлечения, сформированные привычки были нацелены на предстоящую в близком будущем работу в экстремальных условиях...под землей. Это и выработанная за счет закаливания устойчивость к переохлаждению, (в Москве он обходился без верхней одежды вплоть до наступления сильных морозов, а отправляясь в канун студеного 1941 г. в Ленинград, взял с собой лишь легкое летнее пальто). Это и занятия джиуджитсу, позволявшие поддерживать хорошую физическую и боевую форму. Это и способность трудиться, не покладая рук, с раннего утра и до поздней ночи, не прерываясь на прием пищи и воды - именно в таком режиме Лева провел период с конца февраля до начала апреля, когда болезнь обеспечила ему передышку в школьных занятиях. А одним из побудительных мотивов запланированного на лето 1941 г. пешего перехода в Ленинград (конечно, в том случае, если не случиться войны) являлось испытание себя на прочность в походных условиях.

Помимо физической закалки и подготовки, это была и система психотренингов, хотя сам этот термин вряд ли был ему известен. Но именно так можно квалифицировать эксперимент, который он сам определяет как проведение оперы «Аида» у себя в сознании: вначале он это делает дома в расслабленном состоянии, а затем - по дороге в Ленинград, под грохот поезда и шум в вагоне. Используя любимую музыку Верди, Лева заставляет сознание работать одновременно в нескольких регистрах: и стереофонически, хотя и только мысленно, воспроизводить музыкальный текст, и сохранять включенность в окружающую обстановку, вплоть до участия в разговорах с попутчиками, и, самое главное, контролировать эмоциональный настрой. Уже опыт первого погружения в подземелье, с зафиксированным нагнетанием дискомфортных ощущений, поставил перед ним проблему психорегуляции, а Лева решал ее, как всегда изящно и эффективно с помощью незаменимой «Аиды». 
Без сомнений, к этому запасу нужных навыков следует отнести и умение создать фотографически точную зарисовку объекта наблюдения. Именно в этом вопросе ему приходится выдержать наибольшее давление близких, направлявших его в художественную школу и добивавшихся от него выработки собственного почерка. Однако раз за разом без объяснений он отклоняет эти доброхотные увещевания. В свете выявленных намерений отгадка является простой: фотоаппараты его времени не были рассчитаны на съемки в темноте, приходилось полагаться на собственный глазомер и натренированную руку.

Намеченную цель исследования подземных работ он не выпускает из виду даже, совершая подъем на вершину Исаакиевского собора во время своего последней поездки в Ленинград. Так, по ходу восхождения, по словам Левиного отчета, он вместе с товарищем Женей Гуровым продвигается через мрачный коридор, темноту которого изредка прореживают «голубые лучи, называвшиеся, конечно, не иначе, как дневным светом»; далее лестнииа выходит в своеобразную котловину. За верхними колоннами «ила пропастъ». ${ }^{19}$ Вдвоем с Гуровым они карабкаются по ступеням, как ящерицы. Судя по набору слов, явно относящихся к сценарию обследования земных недр, подъем на знаменитую вышку собора он воспринимает под углом зрения подготовки к целенаправленной работе среди подземных богатств.

Так в чем же заключалась эта великая цель Левы, к которой он так упорно шел на протяжении всей своей короткой жизни? Завесу над ней приоткрывает самый важный фрагмент дневника (от 26 июня 1941 г.), посвященный размышлениям о войне и послевоенным перспективам. Приведем его полностью: «Очень прискорбно видеть, ито в данное время силь науки работают на уничтожение человека, а не для завоевания побед над природой. Но уж когда будет разбит последний реакционный притон на Земле - тогда, воображаю, как заживет человечество! Хотелось бы и мне, черт возьми, дожить до этих времен. Коммунизм - великолепное слово! Как оно замечательно звучит рядом с именем Ленина! И когда поставишь рядом с образом Ильича палача Гитлера... Боже! Разве возможно сравнение? Это же безграничные противоположности: светлый ум Ленина и какал-то жалкая злобная мразъ, напоминаюомая... да разве может Гитлер ито-

\footnotetext{
19 Дневник Л. Федотова. Тетрадь XIV. С. 83, 85, 86.
}

нибудь напоминать? Самая презренная тварь на Земле способна казаться ангелом, находясь рядом с этим отпрыском человеческого общества. Как бы я желал, чтобы Ленин сейчас воскрес!.. Эх! Если бы он жил! Как бы я хотел, итобы эти звери-фашисты в войне с нами почувствовали на своих шкурах светлый гений нашего Ильича. Уже тогда бы они сполна почувствовали, на что способен русский народ» 20.

На первый взгляд, данный отрывок состоит из несвязанных между собой суждений. Однако это только видимость, вызванная тем, что автор прибегает к сознательной шифровке своих мыслей за счет опущения отдельных логических связок и использования субститутивных (заместительных) обозначений некоторых понятий. Первая фраза строится на противопоставлении двух функций науки. С одной стороны, это «уничтожение человека», с другой... В привычной системе координат антитезой «уничтожению» человека является сбережение, сохранение жизни. Однако Лева имел в виду отнюдь не этот распространенный антоним - в противном случае он не прибег бы к завуалированному описательному определению - «завоевание побед над природой». В своем имплицитном смысле оно, отсылает, с одной стороны, к законам природы, неподвластным в текущем времени силам науки. С другой, к потенциальному общему торжеству человечества благодаря победам этих же сил. Именно таким смыслом индуцированы вытекающие из первой вторая и третья фразы отрывка, в которых Лева говорит соответственно о предстоящем качественном позитивном переломе жизни на земле и о своем страстном желании застать это время.

В этом контексте значение рассматриваемого словосочетания может быть только абсолютным и полным антиподом «уничтожению человека» и в расширительной логике подлежит восстановлению как «реконструкция, воссоздание» человека. Для эксплицированного выражения мысли Леве требовалось добавить лишь одно прилагательное: «завоевание побед над смертной природой». Однако сама заявка столь беспрецедентна и сомнительна для читателя, что автор прибегает к ее маскировке.

И, тем не менее, дающая зачин всему рассуждению первая фраза в своей пресуппозиции (смысловой презумпции) утверждает способность науки овладеть воскресительными технологиями и тем самым обеспечить бессмертие

\footnotetext{
${ }^{20}$ Дневник Л. Федотова. Тетрадь XV. С. 10.
} 


\section{Исторический журнал: научные исследования № 5 (17) • 2013}

\section{DOI: $10.7256 / 2222-1972.2013 .5 .9248$}

человечеству. По сути, все последующие фразы отрывка, связанные друг с другом линейной прогрессией, нанизываются на эту опущенную, но подразумеваемую посылку. Являлся ремой первого, она становится темой второго, сложного по своему строению высказывания. (Без ее учета нить связного повествования прерывается, и в изложении возникает немотивированный скачок от «завоеваний побед над природой» к разгрому «последнего реакционного притона на земле»). Именно на эту посылку сориентированы два придаточных оборота второго высказывания. Если первый указывает на решающее условие реализации этой великой миссии науки - искоренение очагов зла и насилия (Но уж когда будет разбит последний реакционный притон на Земле...), то второй - на грандиозный результат, которым она увенчается (...воображаю, как заживет человечество!). По замечанию выдающегося отечественного лингвиста Н.Д. Арутюновой, модус восприятия (в данном случае: «воображаю») вместе с «как - придаточным» всегда образует событийное словосочетание, в котором местоимение «как» замещает зависимое от глагола наречие, даже если это наречие не эксплицировано. ${ }^{21}$

В рассматриваемом предложении такое наречие или даже группа наречий легко выделяется из контекста: «...как безгранично счастливо, полноценно заживет человечество». По логической конструкции второе высказывание представляет собой энтимему, то есть усеченный силлогизм, который преобразуется в полный путем введения основания: силы науки обеспечат торжество человечества в бессмертии после очищения его от социального и нравственного зла; очищение человечества от зла состоится в результате разгрома последнего реакционного притона на Земле; силы науки обеспечат торжество человечества в бессмертии после разгрома последнего реакционного притона на земле.

Третья фраза, хотя и не вносит новых штрихов в дескрипцию общества, способного применить эти технологии, однако же, ярко выраженным эмотивным модусом (...хотелось бы мне, черт возьми, дожить...) поддерживает намеченный ранее его идеальный образ. Наконец, четвертая фраза дает его точное название как коммунизма. В сущности, все первые четыpe высказывания (до упоминания имени Ленина и его сравнения с Гитлером) имеют это же

\footnotetext{
${ }^{21}$ Арутюнова Н. Д. Язык и мир человека. М.: Языки русской культуры, 1998. С. 423.
}

понятийное вхождение. Содержание данного концепта последовательно развертывается как человеческое общежитие, преодолевшее внутри себя субстанциональное зло в итоге уничтожения последнего оплота реакции в мире; как общежитие, опирающееся на научные технологии воскрешения умерших и утверждения бессмертного статуса человечества. Эти признаки агрегируются оценочным заключением: «Коммунизм - великолепное слово!», а далее проецируются на образы Ленина и Гитлера. (Как оно замечательно звучит рядом с именем Ленина! И когда поставишь рядом с образом Ильича палача Гитлера...).

С формальной точки зрения попытка приложения имени Гитлера к формуле коммунизма является нонсенсом. Точно так же лишено всякого смысла соединение имен Ленина и Гитлера, в Левином понимании - безграничных противоположностей, в некоем общем ментальном пространстве. Однако в свете заложенного в коммунистический проект упразднения факта смерти такая мысленная операция получала свое обоснование. В логической перспективе досрочного внедрения этого проекта политические антиподы обретали равные шансы, а, по-другому говоря, волею незрелого общества, завладевшего экстраординарными ресурсными возможностями, и тот, и другой получили бы право занять место в рядах бессмертных (т.е. быть поставленными рядом). Это допущение открывает еще одну сторону авторского восприятия воскресительного акта - как общественного дела, базирующегося на коллективном волеизъявлении и коллективном участии всех представителей мирового сообщества. (Грамматически эту всеохватность подчеркивает обобщенно-личный тип предложения «И когда поставишь...» с использованием глагола второго лица, всегда отражающим максимально широкую субъектную включенность в сферу описываемого действия). ${ }^{22}$

Последующее сопоставление двух фигур мировой политики предельно заостряет вопрос об опасности преждевременной реализации поставленной цели. В этих суждениях имена Ленина и Гитлера выступают как бинарная оппозиция, олицетворяющая метафизическую борьбу света и тьмы. Эти коннотации присутствуют в семантических полях словосочетаний: светлый ум, светлый гений Ильича и палач Гитлер, на фоне которого самая презренная тварь на Земле

22 Золотова Г. А. Онипенко Н. К. Сидорова М. Ю. Коммуникативная грамматика русского языка. М.: МГУ, 1998. С. 120. 
способна казаться ангелом. Иначе говоря, гитлеровская сущность внеположна таксономии земного зла, а стало быть, соотносима разве только с Люциферовой демиургией Космоса. Именно поэтому ее соприсутствие самому великому событию в истории землян чревато извращением крупнейшего гуманистического замысла с катастрофическими последствиями вселенского масштаба.

И все-таки, в последних фразах отрывка Лева дает волю своим чувствам, пытаясь представить возвращение Ленина на историческую сцену сейчас, то есть в то самое время, когда звери-фашисты терзают родину. Он уверен: в этом случае изверги-гитлеровцы на своих шкурах сразу бы и сполна почувствовали, на что способен русский народ.

По разумению Левы, временной промежуток, который отделяет его самого и его современников от этого поворотного момента мировой истории не слишком велик, во всяком случае, он надеется встретить его на своем жизненном веку. Он убежден, что СССР выйдет победителем в войне с Германией, несмотря на высокую цену, которую придется уплатить за этот итог. Он уверен в том, что в результате светоносной победы на путь общественно-политического развития, проложенный Советским Союзом, повернут и другие страны мира. Таким образом, сформируются социальные предпосылки, отвечающие предстоящим кардинальным изменениям человеческого существования. Этому не сможет помешать и вероятное противоборство СССР с США и Великобританией:

«Может быть, после победы над фашизмом, в которой я не сомневаюсь, нам случится еще встретиться с последним врагом - капитализмом Америки и Англии, после чего восторжествует абсолютный коммунизм на всей Земле, но эта схватка уже не должна и не может все же быть такой свирепой, как нынешняя наша схватка с фатистской Германией, ибо то будет встреча единич более близких» ${ }^{23}$. Маленькая деталь Левиной дневниковой записи от 23 ноября 1939 г. подтверждает предполагаемую им среднесрочную перспективу осуществления грандиозного глобального проекта. Вспоминая тогда лето 1935 г., проведенное вместе с подругой семьи Анютой на клязьминской даче, он вначале записывает: «В то время был вместе с нами и Саша - ее муж-мой бъьвиий лучший взросльй друг, которого я уже никог-

\footnotetext{
${ }^{23}$ Дневник Л. Федотова. Тетрадь XV. С. 10.
}

$\partial a \ldots{ }^{24}$. Концовка этой фразы легко додумывается: не увижу... Однако, спохватываясь, он вычеркивает из текста безнадежные слова «бывший», «уже», и ставит перед точкой нейтральное: не забуду. Ведь в свете ожидаемых перемен свидание с Сашей еще может состояться!

Итак, похоже, раскрыта главная тайна Левы, манившая и одновременно дразнившая некоторых его друзей (вспомним описание занятий Лени Карася). Она представляет его как последователя философии «общего дела» Н.Ф. Федорова, хотя и воспринятой в ее секулярной версии. Место, время и обстоятельства открытия им этого учения остаются «за кадром», хотя в самом факте еще не заключалось ничего необычного. Образованное общество России начала XX в., охваченное кризисом традиционного религиозного сознания, жадно впитывало откровения «старца» из Румянцевской библиотеки. ${ }^{25}$ Это увлечение затронуло и часть леворадикальной интеллигенции, рассматривавшую тотальный социальный переворот, в том числе, и под углом зрения возможностей осуществления смелых биотехногенных утопий. Быть может, труды философа, изданные после смерти его последователями, имелись в библиотеке Федора Каллистратовича Федотова, быть может, к ним привлек внимание мальчика его взрослый друг Саша. В равной степени, возможно, что в библиотеке кого- либо из знакомых семьи он мог натолкнуться на сборник «Вселенское дело», положившего начало в 1914 г. постоянному федоровскому движению. Эти семена, кто бы их ни уронил, упали на благодатную почву: поиск подходов к практическому исполнению программы воскрешения «отцов» становится смыслом и целью его жизни.

С этим выбором следует связать и зеркальное отражение ряда фундаментальных правил зачинателя учения «патрофикации» (воскрешения отцов) в образе жизни и мыслей его юного советского продолжателя. Аскетизму Федорова, в частности, его обыкновению довольствоваться самым малым в еде, обходиться без верхней одежды зимой, трудиться по восемнадцать-двадцать часов в сутки - корреспондировали аналогичные спартанские привычки и подвижнические принципы Левы. Безграничному альтруизму философа в ученых занятиях и в отношениях с людьми вполне соответствовал идеалистиче-

\footnotetext{
${ }^{24}$ Дневник Л. Федотова. Тетрадь V. C.14.

${ }^{25}$ Агурский М. Идеология национал-большевизма. - Paris: YMCA- press, 1980. 321 c.
} 


\section{Исторический журнал: научные исследования № 5 (17) • 2013}

\section{DOI: $10.7256 / 2222-1972.2013 .5 .9248$}

ский посыл советского подростка «быть полезным» стране и обществу, не замутненный ожиданиями социального признания. А самое главное - свою модель будущего он изначально строил на самой головокружительной мечте о победе над смертью, в обход научно-фантастических грез 1920-1930- х гг. о продлении человеческих жизней путем пересадки органов животных или пролонгации жизнедеятельности мозга после утраты тела. (Вспомним ихтиандра, голову профессора Доуэля у А. Беляева или опыты профессора Преображенского у М. Булгакова). Феномен московского школьника указывает на непрерывность «федоровских» исканий в российском интеллектуальном творчестве. Они не только не оборвалась после того, как на «федоровцев» второй волны (А.К. Горский, Н.А. Сетницкий, В.Н. Муравьев) в 1930-е гг. обрушились репрессии, но и устремились на путь научно-прикладного разрешения идей философа.

Одновременно с тем, интенции московского школьника обнаруживают и существенные отклонения от программы основоположника «общего дела». Прежде всего - в аспекте социальных предпосылок проекта: если Федоров, убежденный противник и социализма, и капитализма, видел его осуществление в форме строительства православного психократического царства, то Федотов уверенно связывал его с коммунистическим будущим, при том скрытым не за дальним горизонтом. В этом представлении он расходился и с «федоровцами» 1920-1930-х гг., усматривавшими в советской власти инструмент воплощения некоторых предвидений, вроде регуляции природных сил, научной организации труда, но не предельного идеала учителя.

Переосмысленная московским школьником концепция Федорова - в расхожих терминах современного гуманитарного знания легко идентифицируется как соединение двух утопий - биокосмической и коммунистической. Еще недавно это определение, под стать хлесткому ярлыку, заведомо выбраковывало бы подобный продукт из объектной сферы серьезного научного рассмотрения. Однако на фоне деградации отечественной фундаментальной науки и развала космической отрасли, сопровождающих весь постсоветский период развенчания «коммунистической утопии», нигилистический подтекст этой формулы теряет основание.

По словам известного американского русиста и советолога Р. Стайтса, советская научно-фантастическая литература и проективная публицистика 1920- х гг. были одержимы двумя главными темами: бессмертием и освоением космоса. При этом, как справедливо подчеркивает историк, к этим миражам потянулась страна, в которой физический потенциал нации был подорван революционными потрясениями и гражданской войной, а деревянная соха и гужевой транспорт составляли примету повседневной жизни. По мнению Стайтса, культ науки и техники являлся общим феноменом для отсталых обществ, находящихся в процессе революционной трансформации. А увлечение идеями Федорова отражало некую блуждающую ментальность, основанную на хилиастических чаяниях народа и прометеевской вере в способность изменить природу и ее законы. ${ }^{26}$

Добавим от себя: какие бы духовные силы не распечатала русская революция - те ли, которые усматривал Стайтс, либо иные, скрытее до поры до времени под пассионарным стремлением к социальному обновлению, они показали эффективную сочетаемость с прорывными научно-технологическими проектами, по меньшей мере, для России. Начавшийся с массового увлечения авиацией в 1930-е годы путь к звездам тремя десятилетиями спустя увенчался открытием СССР эры космонавтики. Дорога к бессмертию оказалась куда сложнее, однако, но и она ознаменовалась в предвоенный период становлением одной их самых передовых систем здравоохранения в мире и победой над многими заболеваниями. Эти неоспоримые свершения 1930-х мотивировали дерзкий вызов, который талантливый московский школьник бросал хтоническим демонам разрушения и тлена.

Была ли эта заявка порывом юношеской самонадеянности, а, если нет, то, как далеко ему удалось продвинуться на взятом направлении? Хронологический расчет Левы, связывающий с послевоенным переустройством мира переход к новому эволюционно-биологическому циклу развития человечества, как будто, свидетельствует в пользу некоторого определившегося у него плана. Можно с уверенностью говорить о ключевой роли в нем палеонтологических изысканий и догадываться о его направленности на претворение ископаемых остатков давно угаснувших жизней в источник новой витальной силы для человека. По-видимому, некая эвристическая идея такого рода блеснула у него летом 1938 г.,

${ }^{26}$ Stites R. Revolutionary Dreams: Utopian Vision and Experimental Life in the Russian Revolution. New York: Oxford University Press, 1989. P. 168-170. 
по ходу осмотра пещер Звенигорода и других занятий натуралиста. Именно тогда и мать, и друзья получили от него по весточке - две одинаковых почтовых открытки с крупно напечатанной на лицевой стороне датой 26 июня 1938 г., на которую были назначены выборы в Верховный Совет РСФСР. Среди нескольких малозначащих фраз об отдыхе он убедительно просит обоих адресатов во что бы то ни стало сохранить этот продукт советской полиграфии. Друзья Левы - Миша Коршунов и Вика Терехова еще много десятилетий спустя будут гадать, что бы значила эта просьба. А журналист и исследователь Ю. Росциус в духе своей генеральной «провидческой» версии предположит, что так Лева иносказательно сообщал о дне и месяце своей скорой гибели (хотя согласно официальному извещению, полученному матерью, она произошла 25 июня 1943 г. под Тулой). Однако, скорее всего, таким способом Лева закреплял первую вешку на маршруте, который должен был привести его к искомому результату. Можно думать, что следующие вехи проходили через некоторые рисунки Левы, и роман «Подземный клад», где сюжет выстраивался с помощью того же приема «меток»указателей, ведущих поисковиков к уникальной находке. Не случайно поздней весной 1941 г. он заказал знакомому фотографу - любителю снимки своих рисунков, надежно, как ему казалось, упрятал рулон белых обоев с летописью земли, тетради с литературными произведениями. Из их фрагментов, наподобие собранного паззла, могла бы сложиться более детальная и ясная картина. Однако война унесла материалы большой проектной работы Левы, за исключением дневника в его заключительной части.

Почему же Лева не составил отдельного связного изложения своей научной гипотезы? Он это и сам разъяснял в дневнике, хотя вроде бы в связи с другим поводом. Так, имея уже гарантию получения билета в Ленинград в канун 1941 г., на расспросы знакомых о своем отъезде он предпочитал отвечать неопределенно: «Вообше... у меня такой существует закон: ни в коем случае никогда не говори заранее. Вот и сейчас! Меня даже, если и спрашивают, еду ли я в Ленинград, я никогда не говорю «еду", а отвечаю: «вероятно» или «может быть». Я буду уверен в поездке лишь тогда, когда билет будет у меня в руке». ${ }^{27}$

Ответственное отношение к словам и поступкам, возведенное Левой в ранг «закона»,

\footnotetext{
${ }^{27}$ Дневник Л. Федотова. Тетрадь Тетрадь XIII. С. 44.
}

многократно возрастало в сфере компетенции естествоиспытателя, ставки в которой в буквальной смысле измерялись ценой жизни. Необходимость тщательного сбора доказательной базы и верификации гипотезы удерживала не только от реляций о ней, но и от откровенных намеков, хотя бы и в дневнике, направляемом в будущее. И, тем не менее, завуалированные отсылки к инновационным идеям, шифрограмма о великом деле возвращения «отцов», которое может осуществиться в послевоенный период, наконец, отмечавшаяся специфика заполнения дневника, подобно шилу в мешке, оставляли свои следы в повествовательной ткани. Это обстоятельство не только не нарушало авторский замысел, но и закладывалось в него, наравне с генеральным аргументом в пользу гипотезы о возможном достижении бессмертия. Совокупность этих знаков выстраивается в закодированный указатель к планам автора, а толчок к его оформлению дает Вторая мировая война.

В предчувствии подступающей к границам СССР военной катастрофы с конца 1939 г. он перестраивает работу над дневником в соответствии с федоровской концепцией хранилища информационных данных личности, обусловливающего возможность повторной «сборки» ее структуры. Такой шанс он оставляет и за собой в случае, если ему самому не доведется принять участие в предсказанной реорганизации жизни на земле. А в том, что морально окрепшее, преображенное человечество раньше (возможно, с его участием) или позже (вероятно, без него) захочет и сможет вернуть предшествующие поколения, он нисколько не сомневается. Собственно, его короткая сознательная жизнь, пронизанная поисками алгоритма решения данной задачи и даже предуготовленными подземными «квартирами» для громадного пополнения землян, служит подтверждением этой убежденности.

Прояснившееся прикладное назначение дневника проливает свет на отмеченные ранее парадоксы, в частности, сознательное уклонение от изложения чужих идей и концепций, как бы они его не увлекали, и, наоборот, методичную фиксацию собственных мыслей, наблюдений, реакций, поступков, самовыражения по ходу диалогов-столкновений и диалогов - рассуждений. Как добросовестный испытатель Лева толково и честно старался запечатлеть себя в аутентичном облике со всеми достоинствами и недостатками. Именно эта объемно проявленная в дневнике натура дает право утверждать, что главной пру- 


\section{Исторический журнал: научные исследования № 5 (17) • 2013}

\section{DOI: $10.7256 / 2222-1972.2013 .5 .9248$}

жиной такой работы являлось не эгоистическое стремление заново войти в жизнь, а научный поиск. Подобно многим великим предшественникам в медицине и фармацевтике, апробировавшим свои открытия на собственном организме или завещавшим собственные органы на дело спасения других жизней, Лева фактически предоставлял свою информационную матрицу в распоряжение исследователей будущего для отработки технологии воссоздания человека.

Впрочем, насколько позволяет судить метод ведения дневника, его замысел не ограничивался собственной персоной. В перспективе осуществления «общего дела» актуальными являлись любые точные свидетельства о каждой личности: в их перекрестных потоках открывалась возможность адекватного восстановления каждого, кто когда-то посетил этот мир. Вряд ли мы ошибемся, если предположим, что с помощью длинных диалогов, доносящих рассуждения, реплики и междометия собеседников, Лева пытался сохранить четкий информационный слепок всех тех, с кем сводила его судьба. Визуальные зарисовки и прямую речь «героев» его повествования можно сравнить с серией моментальных фотоснимков, позволяющей проследить настроение, ход мыслей, индивидуальные склонности человека. Можно догадываться и о мотивах, которые побуждали его уделять особое внимание детям - ведь многим из них война могла оборвать жизнь прежде, чем их личность успела бы раскрыться и отложиться в памяти других людей, а, следовательно, его свидетельства могли бы подарить им еще один шанс!

Дневник прерывается ровно на том месте, в котором он перестает быть источником личной жизненной истории, то есть, когда на его страницы полноформатно врывается война. Впрочем, к тому времени Лева уже успел сделать свой решающий ход, с помощью которого он намеревался переиграть исторический процесс, как правило, неумолимо стирающий отпечатки пребывания субъектов, не успевших выполнить своего жизненного предназначения. За две с половиной недели до начала войны он включил в текст дневника футурологическую выкладку о нападении Германии, ходе боевых действий и конечной победе СССР. Она смотрится чужеродным вкраплением в текст. Во-первых потому что совершенно выпадает из контекста обширной записи от 5 июня, рассказывающей о заботах, занятиях, беседах и мыслях автора за период от возвращения из Ленинграда и до завершения учебного года. А, во-вторых, потому что не находит опоры в содержании его почти ежедневного мониторинга фактов и событий. Искусственность этого включения помечает фраза, неуклюже перекидывающая мостик от сообщения о последнем посещении автором Большого театра к его рассуждению о предстоящей войне: «Мне хочется сейчас упомянуть о моих политических взглядах, которые я постепенно приобрел в зависимости от обстоятельств за все это время». 28

Не являвшийся политическим мыслителем по складу ума и наклонностей, Лева проявлял интерес к сюжетам международной политики в той мере, в какой они потенциально вторгались в судьбу страны, его родных и близких, а также влияли на продвижение его проекта. В то же время сильно развитая интуиция и незаурядные аналитические способности позволяли ему усмотреть тренд в развитии событий, не видный менее тароватым наблюдателями. Так, сопрягая рациональный просчет поведения противника с адекватным представлением о географии, экономике, психологии общества и государственной власти Советского Союза, он создает абсолютно реалистичный набросок предстоящего военного столкновения с последовательными поражениями и успехами каждой из сторон. И, что особенно важно, успевает записать его до того, как предвидение обернется явью. Собственно, на этом и строился расчет. Прогностическому сценарию предстояло стать мощным якорем, способным удержать его труд от исчезновения среди сокрушительных штормов большой истории. Ведь, в конечном счете, сбывшееся предсказание, тем более, судьбоносных событий, неизменно разжигает любопытство и заставляет внимательно, в надежде на новые обретения, штудировать текст, в который оно инкорпорировано. А, значит, выводит на магистральную линию помыслов и устремлений в рамках «общего дела», которые, по словам одного из самых продвинутых «федоровцев» 1920-х гг. В. Муравьева, выполняют «роль побудителей и направителей действия». ${ }^{29}$ Это с одной стороны. А, с другой... блестящая аналитическая разработка о войне выступает порукой тому, что и главный неоконченный проект автора - не добросовестное заблуждение, не блеф и не мистификация. Похоже, этот парень знал, что делал. Недаром же он был «Леонардо»!

\footnotetext{
${ }^{28}$ Дневник Л. Федотова. Тетрадь XIV. С. 77.

${ }^{29}$ Муравьев В. Овладение вре6менем как основная задача организации труда. М.: издание автора, 1924. С. 11.
} 


\section{Библиография:}

1. Агурский М. Идеология национал-большевизма.-Paris: YMCA-press, 1980.

2. Арутюнова Н. Д. Язык и мир человека. М.: Языки русской культуры, 1998.

3. Дневник Л. Ф. Федотова. Тетради V, XIII, XIV, XV.//РГАЛИ. Ф. Л. М. Рошаля.

4. Золотова Г. А. Онипенко Н. К. Сидорова М. Ю. Коммуникативная грамматика русского языка. М.: МГУ, 1998.

5. Коршунов М. Терехова В. Тайны и легенды Дома на набережной. М.: Слово, 2002.

6. Коршунов М. Рулон белых обоев.// Личный архив автора

7. Муравьев В. Овладение временем как основная задача организации труда. М.:издание автора, 1924

8. Разливинский Я. Если бы. Путешествия к центру земли./ Мир фантастики. 2006. № 5 (33) //http://www.mirf.ru/archive. phpshow $=33$

9. Трифонов Ю. Дом на набережной. Повести и рассказы. М.: Детская литература, 2001

10. Трифонова О. Р. О времени и о судьбе. // Трифонов Ю. Отблеск костра. Старик. Исчезновение. М.: Московский рабочий, 1988.

11. Stites R. Revolutionary Dreams: Utopian Vision and Experimental Life in the Russian Revolution. New York: Oxford University Press, 1989.

\section{References:}

1. Agurskiy M. Ideologiya nacional-bol'shevizma.-Paris: YMCA-press, 1980.

2. Arutyunova N. D. Yazyk i mir cheloveka. M.: Yazyki russkoy kul'tury, 1998.

3. Dnevnik L.F.Fedotova. Tetradi V,XIII,XIV,XV.//RGALI. F. L.M. Roshalya.

4. Zolotova G. A. Onipenko N. K. Sidorova M. Yu. Kommunikativnaya grammatika russkogo yazyka. M.: MGU, 1998.

5. Korshunov M. Terehova V. Tayny i legendy Doma na naberezhnoy. M.: Slovo, 2002.

6. Korshunov M. Rulon belyh oboev.// Lichnyy arhiv avtora

7. Murav'ev V. Ovladenie vremenem kak osnovnaya zadacha organizacii truda. M.:izdanie avtora, 1924

8. Razlivinskiy Ya. Esli by. Puteshestviya k centru zemli./ Mir fantastiki. 2006. № 5 (33) //http://www.mirf.ru/archive.phpshow=33

9. Trifonov Yu. Dom na naberezhnoy. Povesti i rasskazy. M.: Detskaya literatura, 2001

10. Trifonova O. R. O vremeni i o sud'be. // Trifonov Yu. Otblesk kostra. Starik. Ischeznovenie. M.: Moskovskiy rabochiy, 1988.

11. Stites R. Revolutionary Dreams: Utopian Vision and Experimental Life in the Russian Revolution. New York: Oxford University Press, 1989. 